Aggregate Concentration in the Global Economy: Issues and Evidence

\author{
Lawrence J. White \\ Stern School of Business \\ New York University \\ lwhite@stern.nyu.edu
}

\begin{abstract}
In this paper I present new and original evidence concerning global aggregate concentration. To my knowledge, this evidence constitutes the first systematic effort to measure global aggregate concentration. The data are available only for the years 1994-2001 and require some compromises and approximations.

For 2001, the largest 500 global companies' employment accounted for $1.60 \%$ of the world labor force, or $9.92 \%$ of OECD employment. These companies' profits amounted to $0.94 \%$ of world GDP or $4.16 \%$ of world gross domestic savings (GDS); their profits also amounted to $1.18 \%$ of OECD GDP or $5.62 \%$ of OECD gross national saving (GNS). Similar estimates are available for the largest 50 global companies.

The time trends for 1994-2001 show a mixed picture. If employment is the basis for the measurements, the largest 50 global companies accounted for a slightly decreasing share of aggregate employment over time. If, instead, profits are the basis for the measurements, then the 50 largest companies accounted for an increasing share over these same years. But this latter trend is likely overstated and is unlikely to be sustained. Future years will yield more data that can be used to check these trends and refine these measurements.
\end{abstract}

JEL Classification Numbers: L11, L19

Key words: aggregate concentration; mergers; global 


\title{
Aggregate Concentration in the Global Economy: Issues and Evidence
}

\author{
Lawrence J. White \\ Stern School of Business \\ New York University \\ lwhite@stern.nyu.edu
}

\section{Introduction}

There is little doubt that the ever-improving processes of telecommunications and data processing, interacting with liberalized governmental policies, are bringing about rising levels of international trade and international capital flows. Further, thropg the 1980s and 1990s the global economy experienced major waves of corporate mergers. ${ }^{1}$

In this context, then, questions about the levels of and trends in aggregate concentration in the global economy -- the share of worldwide economic activity that is accounted for by the largest $\mathbf{X}$ companies -- are interesting ones to ask. This paper addresses those questions, conceptually and empirically. After addressing a number of methodological and data issues, I present new and original evidence concerning global aggregate concentration. To my knowledge, this evidence constitutes the first systematic effort to measure global aggregate concentration.

In summary, suitable data are available only for the years 1994-2001 and require some compromises and approximations. For 2001, the largest 500 global companies' employment accounted for $1.60 \%$ of the world labor force, or $9.92 \%$ of OECD employment. These companies' profits amounted to $0.94 \%$ of world GDP or $4.16 \%$ of world gross domestic savings (GDS); their profits also amounted to $1.18 \%$ of OECD GDP or $5.62 \%$ of OECD gross national saving (GNS). Similar estimates are available for the largest 50 global companies.

\footnotetext{
${ }^{1}$ Documentation and discussion of those merger waves can be found in Golbe and White (1988, 1993), Black (2000), Holmstrom and Kaplan (2001), White (2001), and Pryor (2001a).
} 
The time trends for 1994-2001 show a mixed picture. If employment is the basis for the measurements, the largest 50 global companies accounted for a slightly decreasing share of aggregate employment over time. If, instead, profits are the basis for the measurements, then the 50 largest companies accounted for an increasing share over these same years. But this latter trend is likely overstated and is unlikely to be sustained.

This paper will proceed as follows: I address in Section II the issue of why the measurement of global aggregate concentration is interesting in its own right. The conceptual/measurement issues are discussed in Section III. The evidence from past national studies are summarized in Section IV. Section V discusses the specific data sources and measurements, as well as their limitations, for the global concentration calculations. Section VI presents the new data on global concentration levels and trends. Section VII offers a brief conclusion. 


\section{What Is Global Aggregate Concentration, and Why Is It Interesting?}

\section{A. What is global aggregate concentration?}

The measurement of aggregate global concentration would measure the share of worldwide economic activity (or some proxy for it) that is accounted for by the $\mathbf{X}$ largest companies in the global economy. A "one shot" measurement would yield some information, although there are few standards for comparison and judgment. More information would come from multiple measurements over a period of time, so that trends might be observed.

\section{B. Why is it interesting?}

At the beginning, it is important to emphasize what such a measure of global aggregate concentration would not be: It would not be an antitrust indicator and would not provide guidance as to monopoly (market) power in individual markets. To see why, let us suppose (as a hypothetical example) that the largest 100 companies in the global economy accounted for $100 \%$ of all economic activity, which would surely be considered to be an extreme (and wildly unrealistic) extent of global concentration. Yet, if each of those 100 companies participated in all relevant markets, the level of setler concentration in each of those markets would be indicative of near-perfect competition. ${ }^{2}$

Why then would the measurement of global concentration be of interest? The primary interest in such measurements surely arises from socio-political concerns. To illustrate those concerns, let us take as an example the United States economy. As of 2000, there were 5.5 million corporations, 2.0 million partnerships, 17.7 million non-farm sole

\footnotetext{
${ }^{2}$ The only antitrust concern that might be raised would be that of multi-market contacts among the 100 companies. For discussions of the potential and actual influence of multimarket contacts, see Feinberg (1985), Rhoades and Heggestad (1985), Bernheim and Whinston (1990), and Evans and Kessides (1994).
} 
proprietorships, and 1.8 million farm sole proprietorships. ${ }^{3}$ The overwhelming majority of these enterprises were quite small, consisting of only a few employees each. At the other end of the spectrum, the 100 largest companies, as measured by the Census Bureau, accounted for $11.4 \%$ of private-sector employment and $11.5 \%$ of private-sector payroll in that same year.

Now let us imagine, instead, that the largest 100 companies in the U.S. accounted for all of private sector employment and payroll. The nature of civil society would surely be different in this latter case. The average number of employees per enterprise would be over one million, and the average value added per company would be about $\$ 80$ billion. There would be no small enterprises, no start-ups, no alternative places (beyond the 100) where someone with a new entrepreneurial idea might go to obtain financial support and institutional encouragement. Political power relationships would surely be different as well. Even if there were 1,000 economy-wide companies (rather than 100), and the per-company magnitudes were only one-tenth as large, the fabric of the economic (and socio-political) landscape would surely be very different from what it actually is.

Of course, there may well be pluses as well as minuses for an economy where very large companies are the dominant or sole private-sector employers. Large companies do tend to provide a greater level of employment security and stability than do smaller companies, which may compensate for the greater bureaucracy and reduced flexibility that accompanies greater size. Nevertheless, the important point is that this hypothetical 100company economy would be a very different one from the actual U.S. economy; and it seems likely that a large fraction of the inhabitants of the U.S. would consider such a structure to be inferior to what is currently present. Similar considerations would hold for describing a high level of concentration in the global economy.

Finally, even if an observer is agnostic as to whether the global level of aggregate

\footnotetext{
${ }^{3}$ These data, and those that follow, are drawn from White $(2001,2002)$.
} 
concentration is something that warrants attention and concern (after all, beyond the extreme hypothetical example described above, what constitutes a "high" or "low" number?), measurement of trends -- changes over time -- nevertheless are likely to be of interest: If aggregate concentration is not changing or is decreasing, then anything that might be considered to be a "problem" is not getting worse and may be getting better. 


\section{Measurement Issues}

Since aggregate global concentration is calculated as the share of some measure or measures of global economic activity that is accounted for by the largest $\mathbf{X}$ companies, there are three fundamental measurement issues that must be addressed: (1) What measure or measures of economic activity should be used? (2) What entities should be included in the numerator of the calculation? and (3) Who and what should be included in the denominator? We will address each issue in turn.

\section{A. What measure or measures of economic activity?}

If the relative importance of large companies' economic activity is the concept of interest, then value added -- the difference between the valyg of an enterprise's sales and the value of its purchased inputs (other than labor and capital) ${ }^{4}$-- is surely the best all-around measure. As its name implies, it does indicate the value added of an enterprise. Further, it has the advantage of being comparable across enterprises.

Some other candidate measures -- employment, aggregate wages or payroll, or profits -- are simply components (directly or indirectly) of value added. For example, employment can be viewed as an indirect component of value-added, since it is employment multiplied by the compensation per worker that yields aggregate labor income, which is a direct component of value added.

Although profits in theory are a direct component of value-added, it should be noted that accounting profits-can be a shaky measure to use in comparing economic activity across firms or time periods. ${ }^{5}$ After all, a company's reported pre-tax profits can be affected by the

\footnotetext{
${ }^{4}$ Equivalently, value added is the sum of wages and salaries and other labor costs, plus profits and other capital costs such as amortization and depreciation.

${ }^{5}$ The accounting revelations of 2001-2003 in the U.S. were an additional indication of the potential biases that can enter reported profit data.
} 
vagaries of allowed depreciation and amortization rates -- which can vary across firms depending on the types of assets in which they have invested -- and its post-tax profits can be further affected by corporate tax rates, which again can vary across firms depending on tax brackets and any special provisions in the tax code. Also, the vagaries of the business cycle may have different effects on the profits of different types of firms, including different sizes.

Aggregate sales revenue of firms is often used as a way of measuring the absolute and relative sizes of enterprises. This method was popularized by its use as the criteria for specifying Fortune magazine's "Fortune 500." But the use of sales revenue presents obvious problems of double-counting. For example, suppose a firm that both manufactures and distributes its products decides to spin off its distribution activities into a separate enterprise that buys only from its former affiliate. Where there was previously a single manufacturerdistributor that sold $\$ \mathrm{X}$ in goods per year (embodying $\$ 0.5 \mathrm{X}$ in value added), there are now two firms: a manufacturer that sells (say) $\$ 0.9 \mathrm{X}$ per year (with $\$ 0.4 \mathrm{X}$ in value added), and a distributor that buys the $\$ 0.9 \mathrm{X}$ and resells $\$ \mathrm{X}$ per year. It is far from clear why these latter two firms should each be considered the approximate equal of each other and why the distributor should be considered the larger of the two. Vertical mergers, of course, will reverse this process. Thus, retail firms with relatively thin value-added margins would be over-represented by a sales-based measure; "upstream" firms with greater value-added relative to sales would be under-represented.

Fyther, the "sales revenue" concept is not well-defined for certain service industries. ${ }^{6}$ For example, should sales revenue include the securities sales of a brokerage firm on behalf of its customers? Should the concept include the firm's securities sales from its own portfolio? Both? Neither? In practice, neither category is reported as sales

\footnotetext{
${ }^{6}$ The accounting revelations of 2001-2003 have indicated that even "sales revenue" may be a more elastic concept than had been generally recognized.
} 
revenue. Instead, financial firms register as revenue their interest and fee income, plus any gains from their trading operations. This revenue concept seems appropriate for comparisons with a non-financial firm. But the employees of financial firms primarily think of the sizes of their companies in terms of assets -- which brings us to another candidate measure.

At first glance, a firm's assets appear to be a plausible method to use in measures of aggregate concentration. After all, assets, like employment, would be an indirect component of a firm's value added; when multiplied by the profit rate on those assets, the firm's profits - a direct component of value added -- would be obtained. However, as a practical matter, using firms' assets as the basis for an aggregate concentration measurement presents at least three substantial problems. First, if financial intermediaries, such as banks, insurance companies, and mutual funds are included, there is substantial double-counting, since the assets of these intermediaries largely consist of the liabilities of the enterprises to which they have lent or in which they have invested, with those liabilities in turn having been used to fund the assets of those enterprises.

Second, the presence (until 2001) of two alternative accounting treatments for mergers and acquisitions meant that substantially different levels of assets could appear on an acquiring company's balance sheet, solely because of the acquirer's choice of accounting treatment. For example, in the "pooling" method of accounting, the assets of the acquired company are simply transferred to the acquiring company's balance sheet at their pre-merger balance-sheet values, which would mean relatively lower post-merger asset values. In the "purchase" accounting method, an additional goodwill asset is created and entered on the acquiring company's balance sheet, to reflect the difference between the purchase price and the pre-merger net asset (balance-sheet) value of the acquired company, which would mean relatively higher post-merger asset values. Thus, reported asset values could vary substantially, depending on which accounting treatment was chosen in otherwise identical mergers. 
Third, changes over time in accounting and tax treatment of asset depreciation, amortization, and write-offs, as well as changes in the expensing-versus-writeoff treatment of various categories of costs, could arbitrarily affect reported asset values.

An asset-related measure would be the stock market value of a company's equity shares. However, this measurement base would greatly restrict the "universe" for which aggregate concentration could be measured. For the U.S., for example, only about 15,000 companies are publicly listed; over 20 million enterprises would be excluded from this measurement base. Also, stock market bubbles and crashes could well introduce extraneous noise into such calculations.

Two additional measurement issues should be mentioned: First, no conventional measure will completely encompass the indirect influences of some large franchise-oriented companies (e.g., fast-food restaurant chains or hotel chains), since the structural characteristics of the independent franchisee owners will not be directly included in the company data of the franchiser "parent" (except through royalties and other fees). Second, if the political-economy concern that surrounds aggregate concentration is that of corporate influence and control, then the increasing institutionalization of global stock markets may point instead toward a focus on the few hundred large mutual fund companies and pension fund managers that dominate institutional holdings.

Notwithstanding these last comments, value added is clearly the superior all-around measure of relative economic importance for making comparisons across firms and thus for serving as the basis for measurements of aggregate concentration. Unfortunately, value added has a major practical drawback: It is not regularly reported by companies in their public financial statements, nor is it regularly available (with only a few exceptions ${ }^{7}$ ) in government data that could be used for aggregate concentration ratios. However,

\footnotetext{
${ }^{7}$ One such exception is value added for the largest companies in U.S. manufacturing sector; see White $(2001,2002)$.
} 
governments and their political processes usually place a great deal of emphasis on employment: "jobs" and job creation and losses. Accordingly, a focus on the employment share of large companies may well be an appropriate runner-up measure to value added. ${ }^{8}$ We will use employment for the purposes of discussion below.

\section{B. What entities should be in the numerator?}

The number of employees of the largest $\mathbf{X}$ companies should be included in the numerator of the global aggregate concentration measure. But what constitutes a "company"? Should government enterprises be counted as a company? What about semiautonomous government enterprises? Government enterprises that are publicly traded, with the public's holding a minority share stake? Publicly traded enterprises where the government has a minority stake (but still exercises some control)? Non-profit enterprises? Further, what about the separately incorporated but wholly owned subsidiaries of other companies? Partially owned subsidiaries? Joint ventures? Alliances?

There are no "right" answers to most of these questions. Issues of control are at the heart of the political concern that underlies aggregate concentration and ought to be a guiding principle in any inclusionary selection principles. But the researcher is often at the mercy of whoever has compiled the data and the list of companies. Nevertheless, the inclusionary issues are surely worth keeping in mind.

\section{Who and what should be in the denominator?}

If the employment of the largest $\mathbf{X}$ companies (somehow defined) is in the numerator, then employment should also be in the denominator. But whose employment?

${ }^{8}$ Payroll, profits, and assets are also reported in White $(1980,2001,2000)$. As Hannah (1995) points out, concentration ratios for the same universe of enterprises are likely to be highest when assets are the base and lowest when employment is the base, because large firms tend to be capital-intensive. 
And what categories? Only the private sector? Only non-agricultural (since none of the largest companies are farm-based)? All countries in the global economy? Or just the developed world (since the vast majority of the largest companies are headquartered there)?

Again, there are no "right" answers. Where possible, an array of alternative denominators should be presented.

One additional "denominator" issue should be mentioned: comparability across countries when global measurements are being considered. Reliance on international agency data (which usually involves efforts at standardization) should reduce (if not eliminate) this issue. 


\section{National Measurements}

To this author's knowledge, there have been no previous efforts at measuring global aggregate concentration. The only prior measurements of aggregate concentration have been at the national level. And, except for White (1980, 2001, 2002), Golbe and White (1988), and Pryor (2001a), other attempts at measuring "aggregate" concentration have focused solely on manufacturing or the combined manufacturing and mining sectors (often described as "industrial" concentration). An overview of these prior studies is provided here, to indicate the types of studies and findings that have been made.

White $(2001,2002)$ reports recent measurements of aggregate concentration for the U.S. economy. He reports declining aggregate concentration for the U.S. economy from the 1980s through the late 1990s, based on employment, payroll, and profit data, despite the merger waves of those decades.

For the manufacturing sector in six countries, Hannah (1995) provides estimates of lengthy time series of aggregate concentration. He finds that aggregate concentration for manufacturing rose in all six countries from the late nineteenth century through the middle of the twentieth century, with divergent paths since then. But, regardless of what one distills from this experience with respect to aggregate concentration in manufacturing, it is important to keep in mind that manufacturing is typically less than - a third of private-sector GDP and employment, even in industrial countries (Hannah 1999). ${ }^{9}$

Finally, Scherer and Ross (1990, p. 63) provide a cross-section of "industrial" aggregate concentration levels for ten countries, as of 1985. These data indicate that aggregate concentration tends to be inversely related to a nation's economic size.

\footnotetext{
${ }^{9}$ The manufacturing sector in the U.S. reached a peak of $33.1 \%$ of private-sector GDP in 1955 ; by 1999 it had decreased to $20.5 \%$.
} 


\section{The Data}

\section{A. The numerators.}

As was argued above, value added is generally the best measure (numerator and denominator) for aggregate concentration calculations. But, unfortunately, company compilations do not regularly calculate and report value added. However, employment and profits -- which companies do report -- are fairly good runner-up measures, since the sum of wage costs (which is employment times average employee cost) plus profits approximates value added. Also, employment itself is a major focus of political attention.

The availability of collections of company data involving employment and profits for the calculation of the numerators of any global aggregate concentration measures is quite limited. There are only three candidate sources of data; and, as will be argued, among these three, only one source provides a usable time series.

1. The Financial Times. The Financial Times (ET) publishes annually a list of the 500 largest global companies. The ET list is based on stock market value and extends back to the early 1990s. In the past few years the ET list has also included company sales ("turnover") data in addition to end-of-year stock market values. But, as was argued above, neither stock market value nor company sales is a suitable measure for the calculation of aggregate concentration.

Consequently, the ET 500 series is not suitable for the calculations that are required for this report.

2. Fortune Magazine. Beginning in 1995 (and covering 1994 and after), Fortune magazine has published annually a "500" list of the largest companiqs worldwide, as measured by sales. ${ }^{10}$ Fortune includes the employment and profits ${ }^{11}$ of those 500

10 Prior to 1995, Fortune published global lists, but they were not integrated or comprehensive.

11 A methodological issue that was not raised in the discussion above concerns the 
companies. Fortune also has published separate "leading 50" lists, based separately on company employment and company profits (as well as on other company dimensions).

The Fortune global 500 and 50s lists do provide a suitable data base for use as the numerators in computing employment and profits aggregate concentration ratios for 2001, and they will be used later in this report. Unfortunately, the Fortune lists cannot be used for comparisons over time. This limitation arises because Fortune's criteria for inclusion in their lists have encompassed government-owned enterprises, such as the U.S. Postal System and national railway and postal/telephone systems in Emope and elsewhere. Although this inclusion principle does not itself cause a problem, ${ }^{12}$ in the late 1990s Fortune began including large state-owned Chinese companies in the lists. While only twq-Ghinese companies were listed among the 500 for 1994 , eleven were listed for $2001{ }^{13}$ These companies tended to be large employers, and thus their inclusion artificially boostad the employment totals for the global 500 and also for the global 50 largest employers. ${ }^{14}$ This artificial boosting thus renders the Fortune lists unsuitable for time series comparisons.

exchange rate at which the data for different companies or countries should be converted to a common currency. Fortune uses the average exchange rate for the twelve months covered by a company's annual report to convert all of the profit figures to dollars (as does Forbes).

${ }^{12}$ As was discussed above, these inclusionary criteria constitute a methodological issue to which there is no "right" answer.

${ }^{13}$ These companies existed, at about their same size, prior to their inclusion in the Eortune lists. Thus it was not the growth of these companies that triggered their inclusion; instead, the inclusions occurred as a consequence of Fortune's editorial judgment that these companies' reporting and disclosure standards had risen sufficiently to warrant their inclusion.

${ }^{14}$ Seven Chinese companies were included in the Fortune list of the 50 largest employers for 2001; these seven ranked second, third, fourth, sixth, seventh, ninth, and twenty-first. By contrast, Fortune's list of the leading 50 companies ranked by profits was not affected by the inclusion of the Chinese companies, because those companies tended to be unprofitable. The aggregate profits of the Fortune list of the 50 most profitable companies, for the years 1994-2001, correlates almost perfectly $(r=0.99)$ with the Eorbes profits data discussed and used below. Only one Chinese company (ranked twenty-third) was in the list of 50 most profitable companies for 2001. 
3. Forbes Magazine. Also beginning in 1995 (and covering 1994 and after), Forbes magazine has published annually a list of global "Super 50" companies, which Forbes ranks as the largest global companies, based on a composite calculation of sales, profits, employment, and market value. Though Forbes does not provide the specifics of its composite formula, that formula does not appear to have changed appreciably over the period. Also, Forbes includes only publicly traded companies, so the Chinese company inclusions that cause the Fortune lists to be unsuitable for time series comparisons are not present in the Forbes lists.

Accordingly, the aggregate employment and aggregate profits data from the Forbes global "Super 50" lists, from 1994 through 2001, will be used as the numerators for the global aggregate concentration measurements, for 2001 and for time series comparisons, that are presented later in this report.

\section{B. The denominators.}

Since employment and profits constitute the numerators of the aggregate concentration calculations of this report, similar measurement bases are desirable for the denominator. As will be seen, some compromises are necessary.

Since the aim of the calculations is global aggregate concentration measurements, the denominator ought to be based on similarly measured world economy data. Unfortunately, the most suitable world egonomy data -- drawn from the World Bank's "World Development Indicators" series ${ }^{15}$-- can only provide approximations. As the denominator for the employment calculation, only a series for the world aggregate labor force is available. ${ }^{16}$ As the denominator for the profits calculation, the World Bank data

15 Other data sources, such as the United Nations and the International Labour Organization -- were searched for data that were comparable to the Fortune and Forbes employment and profits data and that also covered 1994-2001. These sources did not yield suitable data.

${ }^{16}$ There is no series on world employment, let alone world private sector employment. 
yield two candidate series: wejld aggregate nominal GDP, and world aggregate nominal gross domestic saving (GDS). ${ }^{17}$

In addition to the world economy data, aggregate data for the countries that are members of the Organisation for Economic Co-operation and Development (OECD) are also used as the denominator, because all of the Forbes "Super 50" companies are headquartered in OECD countries and the overwhelming majority of the Fortune 500 companies are headquartered in OECD cpmntries; accordingly, a comparison with the OECD aggregates should be informative. ${ }^{18}$ For the employment calculation, OECD aggregate employment is used. For the profits calculation, OECD aggregate nominal fDP and aggregate nominal gross national saving (GNS) are candidates for the denominator. ${ }^{19}$

${ }^{17}$ There is no world profits series. World aggregate GDP is a candidate, since it is a flow measurement representing general global economic activity; world aggregate GDS is a candidate because it is a flow and because profits should be an important component of saving. In both cases, nominal data are used, because the Eorbes profit data are in nominal terms.

${ }^{18}$ Since almost all of the companies that are headquartered in the OECD have worldwide operations, the OECD aggregates are (in principle) too narrow and do not provide a sufficiently broad basis for an exact comparison. Nevertheless, alongside a world economy calculation, the OECD aggregates provide an additional useful comparative perspective.

${ }^{19}$ As was true for the world economy data, there is no OECD series on profits. 


\section{Global Aggregate Concentration Calculations}

Table 1 provides the basic data that are used in this study. In Panel A the first four columns provide the Fortune global employment and profits data for 2001 only; the next two data columns provide the employment and profits data from the Eorbes global "Super 50" series for 1994-2001. As was discussed above, the Eqrtune and Forbes data provide the numerators for the aggregate concentration calculations. ${ }^{20}$

In Panel B the first three data columns provide the world labor force, nominal GDP, and neminal GDS data. The final three columns provide the OECD employment, nominal $\mathrm{GDP}^{21}$ and nominal GNS ${ }^{22}$ data. These world and OECD data provide the denominators for the aggregate concentration calculations.

\section{A. Global aggregate concentration ratios in 2001 .}

Table 2 provides the calculation of the global aggregate concentration ratios for 2001, using the employment and profits data for the Eortune global 500 and 50 largest companies and the Forbes global "Super 50" companies as the numerators and the

${ }^{20}$ Despite its name, the Eorbes "Super 50" series lists 51 companies for 2001, because there were two companies that apparently yielded identical composite scores for the 50th place in the list. To keep the series consistent with the 50 companies presented for the previous years, I averaged the employment and profit values for the two "50th" companies to compute the 50-company totals for 2001 .

${ }^{21}$ The OECD nominal GDP data are available only in index number form. In order to provide a dollar flow series that is directly comparable to the Eorbes profit data, I used the World Bank's aggregate GDP figure for "high income" countries for 2000 and then multiplied that value by the index numbers to achieve comparable dollar numbers for the other years in the series. The individual numbers in this series should thus be seen as approximations, but their year-to-year relative values -- and thus their usefulness in providing year-to-year comparisons with the Forbes profit data -- remain intact. The same caveat applies to the nominal gross national saving data.

${ }^{22}$ See the previous footnote. 
comparable world and OECD aggregates as the denominators. As the table indicates, the Fortune 500 companies accounted for $1.60 \%$ of the world labor force in 2001 , and $9.92 \%$ of OECD employment. The Fortune list of the largest 50 employers employed $0.64 \%$ of the world labor force and $3.96 \%$ of OECD employment. ${ }^{23}$ And the Forbes "Super $5 \square^{\prime}$ companies employed $0.26 \%$ of the world labor force and $1.63 \%$ of OECD employment. ${ }^{24}$ Similarly, the Fortune 500 companies' profits amounted to $0.94 \%$ of world GDP, etc.

Because there are no previous measurements of global aggregate concentration, there are no good bases for comparison. There are no absolute standards fr definitive ways of knowing whether these figures represent "high" or "low" numbers. ${ }^{25}$ However, any notion that large companies somehow "dominate" the world economy must surely be tempered by the revelation that the largest 500 companies accounted for only $1.60 \%$ pf the world labor force in 2001, and their profits amounted to less than $1 \%$ of world GDP. ${ }^{26}$

The Eorbes data permit a limited period of time series comparisons, allowing an over-time perspective. It is to those time series comparisons that we now turn.

\section{B. The time series data.}

${ }^{23}$ Recall, however, that seven companies in the Fortune employment 50 are Chinese companies that operate largely within China. Those seven accounted for about 5.1 million of the 19.1 million employees in those 50 companies.

${ }^{24}$ The Fortune 50 employment number is substantially above the Forbes "Super 50" employment number because the former represents the selection of the largest employers and includes the large Chinese companies, whereas the Eorbes "Super 50" represent a composite ranking and includes only publicly traded companies.

${ }^{25}$ It is worth noting, however, that these global concentration ranges are substantially below the recent national (U.S.) aggregate concentration measurements reported by White (2001, 2002).

26 Even if (somehow) agricultural production and government activities could be excluded from the denominators, so that the denominators were private-sector nonagricultural employment and value added, it seems unlikely that the aggregate concentration ratios would rise appreciably in absolute terms. 
We now return to the data in Table 1 and explore its time series aspects. As can be seen, the Forbes employment data move erratically and grow very slowly over the eight years of data; by comparison the profit data grow steadily and rapidly, but then fall substantially in 2001. The world labor force data grow slowly but steadily, as does the OECD employment data; the world nominal GDP and GDS grow somewhat faster, and the OECD nominal GDP and GNS grow yet faster.

There are two convenient ways of providing somewhat more precision to the growth characterizations of these time series. The first is to compare the value for the first year of a series with the value for the last year of that series and then calculate the average compounded annual rate of growth between the two years. The results of these calculations are presented in the first data column of Table 3. Using this method, we see that the Forbes employment data did not grow appreciably between 1994 and 2001, while the world laber force grew by $1.7 \%$ per year and OECD aggregate employment grew by $1.1 \%$ per year. ${ }^{27}$ The Forbes profit data grew by $11.6 \%$ annually, while the world nominal GDP grew by $3.0 \%$ and world nominal GDS grew by $2.8 \%$; OECD nominal GDP grew by $6.2 \%$, and OECD nominal GNS grew by $6.9 \%$.

The second method for characterizing a time series is to convert the series to natural logarithms and calculate a regression of the logged time series against the calendar years. The resulting coefficient on the logged time series represents the overall average compounded annual rate of growth, which takes into accemnt the data from all of the years and does not rely solely on the first and last years' data. ${ }^{28}$ The results of this method are presented in the second data column of Table 3. As can be seen, this method yields an annual rate of increase for the Eorbes employment data of $1.1 \%$, while the world labor force data rose at an annual rate of $1.7 \%$ and the OECD employment data rose at a rate of $1.1 \%$.

\footnotetext{
${ }^{27}$ All of the first-year/last-year calculations assume continuous compounding.

${ }^{28}$ In essence, the regression fits a time trend line to the logged data points.
} 
The Eorbes profit data rose at a rate of $14.1 \%$, while the world nominal GDP rose at a rate of $2.3 \%$ and world nominal GDS rose at a rate of $1.9 \%$; OECD nominal GDP rose at a $6.2 \%$ rate, and OECD nominal GNS rose at a $6.7 \%$ rate.

In sum, the Eorbes employment data grew at an annual rate that was the same as or was below the comparable aggregates for the world and for the OECD, while the Forbes profit data grew at a rate that was substantially faster than the growth rates of the roughly comparable world and OECD aggregates. We would expect these comparative rates of growth to translate into constant or falling aggregate concentration ratios for employment and rising ratios for profits. That expectation is confirmed in the next section.

\section{Global aggregate concentration ratios, 1994-2001.}

In Table 4 we present the global aggregate concentration ratios for 1994-2001, using the Forbes data in Table 1 as the numerators; these ratios are also graphed in Figures 1-3. As can be seen, the employment levels of the Forbes "Super 50" global companies accounted for a slightly decreasing share of the world labor force or of OECD employment over time. By contrast, the profit levels on the Forbes "Super 50" global companies accounted for an increasing share of the roughly comparable aggregates for the world or the OECD over these same years.

Again, as was true for the constituent time series, we can characterize the movement over time of these fatios either through a first-year/last-year comparison or through a time series regression. ${ }^{29}$ These characterizations are presented in Table 5. Using the firstyear/last-year comparisons, we see that the employment aggregate concentration ratio fell by 0.005 percentage points per year (with the world labor force as the denominator) or by 0.02 percentage points (with OECD employment as the denominator); the profit aggregate

29 Since the aggregate concentration ratio data are already in percentage form, the calculation of annual percentage point changes seems most straightforward. Consequently, compounding and logarithms are not required. 
concentration ratios rose by 0.05 percentage points per year (with world nominal GDP as the denominator), by 0.22 percentage points per year (with world nominal GDS as the denominator), by 0.04 percentage points (with OECD nominal GDP as the denominator), or by 0.18 percentage points (with OECD nominal GDS as the denominator).

If instead we use the time series regression coefficients (in the second data column of Table 5), the employment ratio fell by 0.002 percentage points per year (with the world labor force as the denominator) or by 0.001 percentage points per year (with OECD employment as the denominator); the profit ratio rose by 0.07 percentage points per year (with world nominal GDP as the denominator), by 0.32 percentage points (with world nominal GDS as the denominator), by 0.07 percentage points (using OECD nominal GDP as the denominator), or by 0.30 percentage points (using OECD nominal GDS as the denominator).

\section{Some reflections on these trends.}

The data for the 1994-2001 period are clear: If employment is the basis for the global aggregate concentration measurements, then the largest global companies accounted for a slightly declining share of the global aggregates. If profit levels are the basis for the measurements, then the largest global companies accounted for a rising share.

The slightly declining share of large companies' employment levels is consistent with the trend for the U.S. found by White $(2001,2002)$. Despite the merger wave of the 1990s, very large companies have not experienced significant relative expansions of employment. This outcome has been partly due to internal rationalizations and cost-cutting by these companies and party due to significant numbers of spinoffs and divestitures of "pieces" of large companies. ${ }^{30}$

${ }^{30}$ As is pointed out in White $(2001,2002)$, about a third of the transactions that appear in the widely reported "merger and acquisitions" (M\&A) annual lists are actually divestitures or spinoffs. 
Similarly, the rising absolute levels of large company profits are consistent with the trend found for the U.S. by White (2001, 2002), although the upward trend seems to be sharper for the international group. But economy-wide profits in the U.S. were also rising rapidly during the late 1990s, so the ratio for the U.S. was relatively constant during the late 1990s. Consequently, the pattern of rising profit ratios documented in this report is at least partly due to the absence of a profits measure for the denominators and the reliance instead on nominal GDP or domestic saving measures. If aggregate global (or OECD) profits have been rising relative to nominal GDP or domestic saving, then using (the slower growing) GDP or domestic saving as the denominator for the profit-based global aggregate concentration measurements necessarily overstates the apparent rising trend of large company importance.

A second factor that should be considered with respect to profits is the likely overstatement of large company profits that was revealed in during 2001-2003 to have been the case for a number of large companies in the U.S. in the late 1990s and early 2000s. Again, this would indicate a likely overstatement of the rising relative importance of large companies' profits.

Nevertheless, it seems quite possible that there was a net rising importance of large companies in the late 1990s, when measured by their profits. However, this rising trend seems unlikely to be sustained, as is indicated by the sharp downturn displayed in 2001 .

One other feature of the Forbes "Super 50" lists is worth noting: the nationalities of the headquarters of those companies. Table 6 lists the number of companies that were headquartered in each country in 1994 and 2001. As can be seen, the largest number of companies were headquartered in the U.S. in both years, and the number of U.S.-based companies increased between the two years, as did those headquartered in the Netherlands. The number of companies headquartered in Japan, Germany, and the U.K. fell; companies headquartered in France, Spain, Italy, and Bermuda entered the ranks; and the number of companies headquartered in Switzerland held constant. 


\section{Conclusion}

This essay has presented new and original measurements of global aggregate concentration for the years 1994-2001. The data, albeit imperfect and sketchy, show that the largest global companies accounted for a slightly decreasing share of global employment, but a rising share of global profits. The former trend is consistent with that found for the U.S. for the late 1990s. The latter trend is different but is likely overstated and is unlikely to be sustained.

Future years will yield more data that can be used to check these trends and refine these measurements. 


\section{References}

Bernheim, B. Douglas and Michael D. Whinston, "Multimarket Contact and Collusive Behavior," Rand Journal of Economics, 21 (Spring 1990), pp. 1-25.

Black, Bernard S., "The First International Merger Wave (and the Fifth and Last U.S. Wave)," University of Miami Law Review, 54 (2000), pp. 799-818.

Evans, William N. and Ioannis N. Kessides, "Living by the 'Golden Rule': Multi-Market Contact in the U.S. Airline Industry," Quarterly Journal of Economics, 109 (May 1994): 341-366.

Feinberg, Robert, "Sales-at-Risk: A Test of Mutual Forbearance Theory of Conglomerate Behavior," Journal of Business, 58 (April 1985), pp. 225-241.

Golbe, Devra L. and Lawrence J. White, "A Time Series Analysis of Mergers and Acquisitions in the U.S. Economy," in Alan J. Auerbach, ed., Corporate Takeovers: Causes and Consequences. Chicago: University of Chicago Press, 1988, pp. 265-302.

Golbe, Devra G. and Lawrence J. White, "Catch a Wave: The Time Series Behavior of Mergers," Review of Economics and Statistics, 75 (August 1993), pp. 493-499.

Hannah, Leslie, "The Joint Stock Company, Concentration and the State, 1894-1994)," in Adrian Allan, ed., Proceedings of the Annual Conference 1994, Business Archives Council. London: Business Archives Council, 1995, pp. 52-77.

Hannah, Leslie, "Marshall's 'Trees' and the Global 'Forest': Were 'Giant Redwoods' Any Different?" in Naomi R. Lamoreaux, Daniel M.G. Raff, and Peter Temin eds., Learning by Doing in Markets, firms, and Countries. Chicago: University of Chicago Press, 1999, pp. 253-285.

Holmstrom, Bengt and Steven N. Kaplan, "Corporate Governance and Merger Activity in the United States: Making Sense of the 1980s and 1990s," Journal of Economic Perspectives, 15 (Spring 2001), pp. 121-144.

Pryor, Frederick L., "Will Most of Us Be Working for Giant Enterprises by 2028?" Journal of Economic Behavior and Organization, 44 (April 2001a), pp. 363-382.

Pryor, Frederick L., "Dimensions of the Worldwide Merger Wave," Journal of Economic Issues, 35 ( December 2001b), pp. 825-840.

Rhoades, Stephen A. and Arnold Heggestad, "Multimarket Interdependence and Performance in Banking: Two Tests," Antitrust Bulletin, 30 (1985), pp. 975-995.

Scherer, F.M. and David Ross, Industrial Market Structure and Economic Performance, 3rd 
edn. Boston: Houghton-Mifflin, 1990.

White, Lawrence J., "What Has Been Happening to Aggregate Concentration in the United States?" Journal of Industrial Economics, 29 (March 1981), pp. 223-230.

White, Lawrence J., "What's Been Happening to Aggregate Concentration? (And Should We Care?)" Working Paper \# EC-02-03, Stern School of Business, New York University, December 3, 2001.

White, Lawrence J., "Trends in Aggregate Concentration in the United States," Journal of Economic Perspectives, 16 (Fall 2002), pp. 137-160. 
Table 1: The Data Used for the Calculation of Global Aggregate Concentration Ratios, 1994-2001

\begin{tabular}{|c|c|c|c|c|c|c|}
\hline & $\begin{array}{l}\text { Fortune Glob } \\
\text { Largest Com }\end{array}$ & A: Large & $\begin{array}{l}\text { Company Dat: } \\
\text { Fortune Glob } \\
\text { Largest Empl } \\
\text { Most Profitab } \\
\text { Companies }\end{array}$ & $\begin{array}{l}\text { ('the Num } \\
150 \\
\text { yers or } \\
\text { e }\end{array}$ & $\begin{array}{l}\text { Forbes Glob } \\
50 \text { " Compan }\end{array}$ & "Super \\
\hline Year & $\begin{array}{l}\text { Employment } \\
\text { (million) }\end{array}$ & $\begin{array}{c}\text { Profits } \\
\text { (\$ billion) }\end{array}$ & $\begin{array}{c}\text { Employment } \\
\text { (million) }\end{array}$ & $\begin{array}{c}\text { Profits } \\
\text { (\$ billion) }\end{array}$ & $\begin{array}{l}\text { Employment } \\
\text { (million) }\end{array}$ & $\begin{array}{c}\text { Profits } \\
\text { (\$ billion) }\end{array}$ \\
\hline 1994 & $-^{\mathrm{a}}$ & $-^{\mathrm{a}}$ & $-{ }^{\mathrm{a}}$ & $-^{\mathrm{a}}$ & 7.8 & $\$ 109$ \\
\hline 1995 & $-^{\mathrm{a}}$ & $-^{\mathrm{a}}$ & $-^{\mathrm{a}}$ & $-^{\mathrm{a}}$ & 7.2 & 112 \\
\hline 1996 & $-^{\mathrm{a}}$ & $-{ }^{a}$ & $-^{\mathrm{a}}$ & $-^{a}$ & 6.9 & 154 \\
\hline 1997 & $-^{a}$ & $-{ }^{\mathrm{a}}$ & $-^{\mathrm{a}}$ & $-^{a}$ & 7.3 & 182 \\
\hline 1998 & $-^{\mathrm{a}}$ & $-{ }^{a}$ & $-^{\mathrm{a}}$ & $-^{\mathrm{a}}$ & 7.1 & 180 \\
\hline 1999 & $-{ }^{\mathrm{a}}$ & $-^{\mathrm{a}}$ & $-^{\mathrm{a}}$ & $-^{\mathrm{a}}$ & 7.6 & 218 \\
\hline 2000 & $-^{\mathrm{a}}$ & $-^{\mathrm{a}}$ & $-{ }^{a}$ & $-^{a}$ & 8.2 & 311 \\
\hline 2001 & 47.8 & $\$ 306$ & 19.1 & $\$ 280$ & $7.8^{\mathrm{b}}$ & $245^{b}$ \\
\hline
\end{tabular}

Panel B: Global Aggregates ("the Denominators")

\begin{tabular}{|c|c|c|c|c|c|c|}
\hline & \multicolumn{3}{|c|}{ World Economy } & \multicolumn{3}{|c|}{ OECD Countries } \\
\hline Year & $\begin{array}{c}\text { Labor } \\
\text { Force } \\
\text { (million) }\end{array}$ & $\begin{array}{l}\text { Nominal } \\
\text { GDP } \\
\text { (\$ billion) }\end{array}$ & $\begin{array}{c}\text { Nominal } \\
\text { Gross } \\
\text { Domestic } \\
\text { Saving } \\
\text { (GDS) } \\
\text { (\$ billion) }\end{array}$ & $\begin{array}{l}\text { Employment } \\
\text { (million) }\end{array}$ & $\begin{array}{l}\text { Nominal } \\
\text { GDP } \\
\text { (\$ billion })^{\mathrm{c}}\end{array}$ & $\begin{array}{l}\text { Nominal } \\
\text { Gross } \\
\text { National } \\
\text { Saving } \\
\text { (GNS) } \\
\text { (\$ billion) }\end{array}$ \\
\hline 1994 & 2,617 & $\$ 26,458$ & $\$ 6,026$ & 447 & $\$ 16,843$ & $\$ 3,369$ \\
\hline 1995 & 2,662 & 29,244 & 6,769 & 452 & 18,190 & 3,765 \\
\hline 1996 & 2,709 & 29,938 & 6,865 & 457 & 19,537 & 4,064 \\
\hline 1997 & 2,756 & 29,802 & 6,915 & 464 & 20,885 & 4,490 \\
\hline 1998 & 2,804 & 29,603 & 6,700 & 469 & 22,232 & 4,780 \\
\hline 1999 & 2,850 & 30,667 & 6,856 & 474 & 23,411 & 4,893 \\
\hline 2000 & 2,896 & 31,493 & 7,102 & 480 & 24,927 & 5,210 \\
\hline 2001 & 2,943 & $32,595^{\mathrm{d}}$ & $7,350^{\mathrm{d}}$ & 482 & 25,938 & $5,447^{\mathrm{d}}$ \\
\hline
\end{tabular}

${ }^{\text {a }}$ See text for explanation

${ }^{\mathrm{b}}$ See text for details of calculation.

${ }^{\mathrm{c}}$ See text for details of calculation.

${ }^{\mathrm{d}}$ Estimated.

Sources: Fortune; Forbes; World Bank; OECD. 
Table 2: Global Aggregate Concentration Ratios, 2001

\begin{tabular}{|l|c|c|c|}
\hline & $\begin{array}{c}\text { Eortune } \\
\text { Global 500 }\end{array}$ & $\begin{array}{c}\text { Fortune } \\
\text { Global 50 }\end{array}$ & $\begin{array}{c}\text { Forbes Global } \\
\text { "Super 50" }\end{array}$ \\
\hline Employment: & & & \\
\hline World labor force as denominator & $1.60 \%$ & $0.64 \%$ & $0.26 \%$ \\
\hline OECD employment as denominator & 9.92 & 3.96 & 1.63 \\
\hline Profits: & & & \\
\hline World nominal GDP as denominator & 0.94 & 0.86 & 0.75 \\
\hline World nominal GDS as denominator & 4.16 & 3.81 & 3.33 \\
\hline OECD nominal GDP as denominator & 1.18 & 1.08 & 0.94 \\
\hline OECD nominal GNS as denominator & 5.62 & 5.14 & 4.50 \\
\hline
\end{tabular}


Table 3: Annual Rates of Growth, 1994-2001

\begin{tabular}{|l|c|c|}
\hline & $\begin{array}{c}\text { First-Year/Last-Year } \\
\text { Comparison }\end{array}$ & $\begin{array}{c}\text { Logged Time Series } \\
\text { Regression Coefficient }\end{array}$ \\
\hline Forbes employment & $0.04 \%$ & $1.1 \%$ \\
\hline Forbes profits & 11.6 & 14.1 \\
\hline World labor force & 1.7 & 1.7 \\
\hline World nominal GDP & 3.0 & 2.3 \\
\hline World nominal GDS & 2.8 & 1.9 \\
\hline OECD employment & 1.1 & 1.1 \\
\hline OECD nominal GDP & 6.2 & 6.2 \\
\hline OECD nominal GNS & 6.9 & 6.7 \\
\hline
\end{tabular}


Table 4: Global Aggregate Concentration Ratios, 1994-2001

Panel A: Forbes Global "Super 50" Companies' Employment

\begin{tabular}{|c|c|c|}
\hline Year & $\begin{array}{c}\text { World Labor Force as the } \\
\text { Denominator }\end{array}$ & $\begin{array}{c}\text { OECD Employment as the } \\
\text { Denominator }\end{array}$ \\
\hline 1994 & $0.29 \%$ & $1.75 \%$ \\
\hline 1995 & 0.27 & 1.60 \\
\hline 1996 & 0.25 & 1.50 \\
\hline 1997 & 0.26 & 1.57 \\
\hline 1998 & 0.25 & 1.52 \\
\hline 2000 & 0.26 & 1.60 \\
\hline 2001 & 0.28 & 1.71 \\
\hline
\end{tabular}

Panel B: Forbes Global "Super 50" Companies' Profits

\begin{tabular}{|l|c|c|c|c|}
\hline & \multicolumn{2}{|c|}{ World Economy Data } & \multicolumn{2}{c|}{ OECD Data } \\
\hline Year & $\begin{array}{c}\text { Nominal GDP } \\
\text { as the } \\
\text { Denominator }\end{array}$ & $\begin{array}{c}\text { Nominal GDS } \\
\text { as the } \\
\text { Denominator }\end{array}$ & $\begin{array}{c}\text { Nominal GDP } \\
\text { as the } \\
\text { Denominator }\end{array}$ & $\begin{array}{c}\text { Nominal GNS } \\
\text { as the } \\
\text { Denominator }\end{array}$ \\
\hline 1994 & $0.41 \%$ & $1.81 \%$ & $0.65 \%$ & $3.24 \%$ \\
\hline 1995 & 0.38 & 1.65 & 0.62 & 2.97 \\
\hline 1996 & 0.51 & 2.24 & 0.79 & 3.79 \\
\hline 1997 & 0.61 & 2.63 & 0.87 & 4.05 \\
\hline 1999 & 0.61 & 2.69 & 0.81 & 3.77 \\
\hline 2000 & 0.71 & 3.18 & 0.93 & 4.46 \\
\hline 2001 & 0.99 & 4.38 & 1.25 & 5.97 \\
\hline
\end{tabular}


Table 5: Annual Percentage Point Changes in Aggregate Concentration Ratios

\begin{tabular}{|l|c|c|}
\hline & $\begin{array}{c}\text { First-Year/Last-Year } \\
\text { Comparison }\end{array}$ & $\begin{array}{c}\text { Time Series Regression } \\
\text { Coefficient }\end{array}$ \\
\hline $\begin{array}{l}\text { Forbes “Super 50" company } \\
\text { employment/world labor force }\end{array}$ & -0.005 & -0.002 \\
\hline $\begin{array}{l}\text { Forbes "Super 50" company } \\
\text { employment/OECD employment }\end{array}$ & -0.02 & -0.001 \\
\hline $\begin{array}{l}\text { Eorbes "Super 50" company } \\
\text { profits/world nominal GDP }\end{array}$ & 0.05 & 0.07 \\
\hline $\begin{array}{l}\text { Forbes "Super 50" company } \\
\text { profits/world nominal GDS }\end{array}$ & 0.22 & 0.32 \\
\hline $\begin{array}{l}\text { Forbes "Super 50" company } \\
\text { profits/OECD nominal GDP }\end{array}$ & 0.04 & 0.07 \\
\hline $\begin{array}{l}\text { Forbes "Super 50" } \\
\text { company/OECD nominal GNS }\end{array}$ & 0.18 & 0.30 \\
\hline
\end{tabular}


Table 6: Headquarters Countries for the Forbes "Super 50" Companies, 1994 and 2001

\begin{tabular}{|l|c|c|}
\hline Country & \multicolumn{2}{|c|}{ Number of Companies } \\
\hline & 1994 & 2001 \\
\hline United States & 23 & 26 \\
\hline Japan & 8 & 2 \\
\hline United Kingdom & 7 & 6 \\
\hline Germany & 6 & 3 \\
\hline Netherlands & 3 & $4.5^{\mathrm{a}}$ \\
\hline Switzerland & 3 & 3 \\
\hline France & - & $2.5^{\mathrm{a}}$ \\
\hline Spain & - & 1 \\
\hline Italy & - & 1 \\
\hline Bermuda & - & 1 \\
\hline
\end{tabular}

a In 2001, the Forbes "Super 50" company list included 51 companies. The two " 50 "th", companies were the Societe Generale Group (of France) and Unilever (of the Netherlands). 


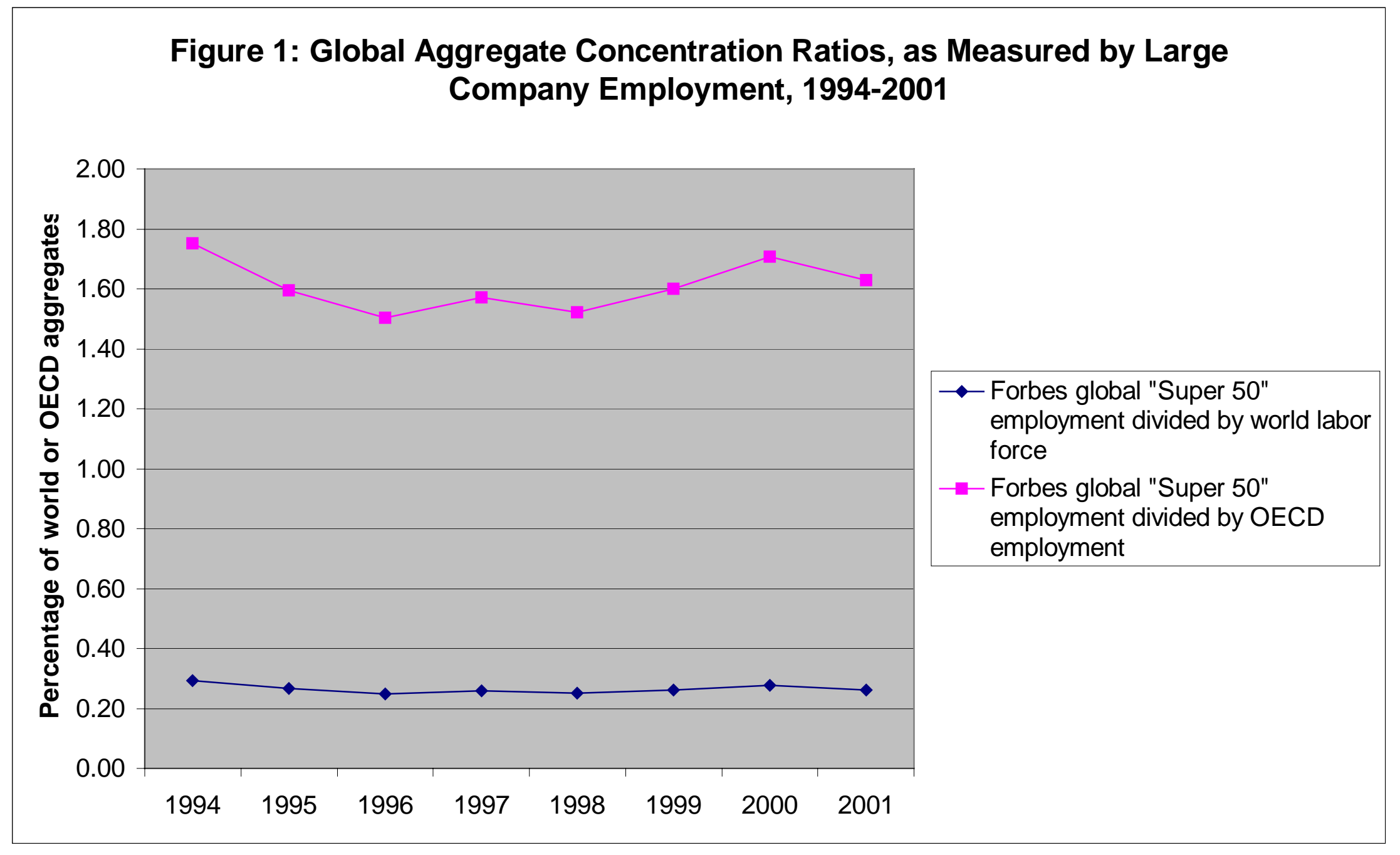




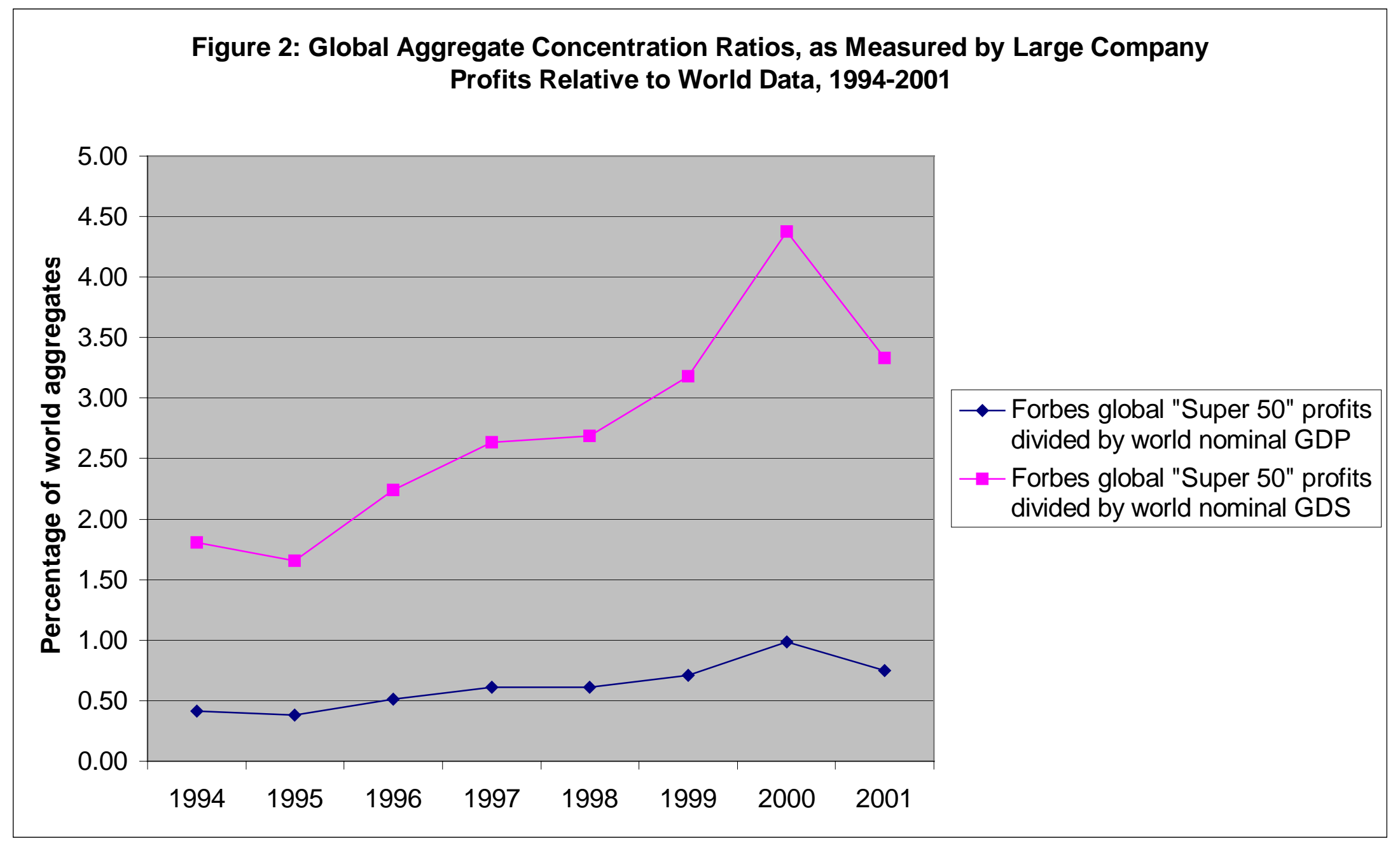




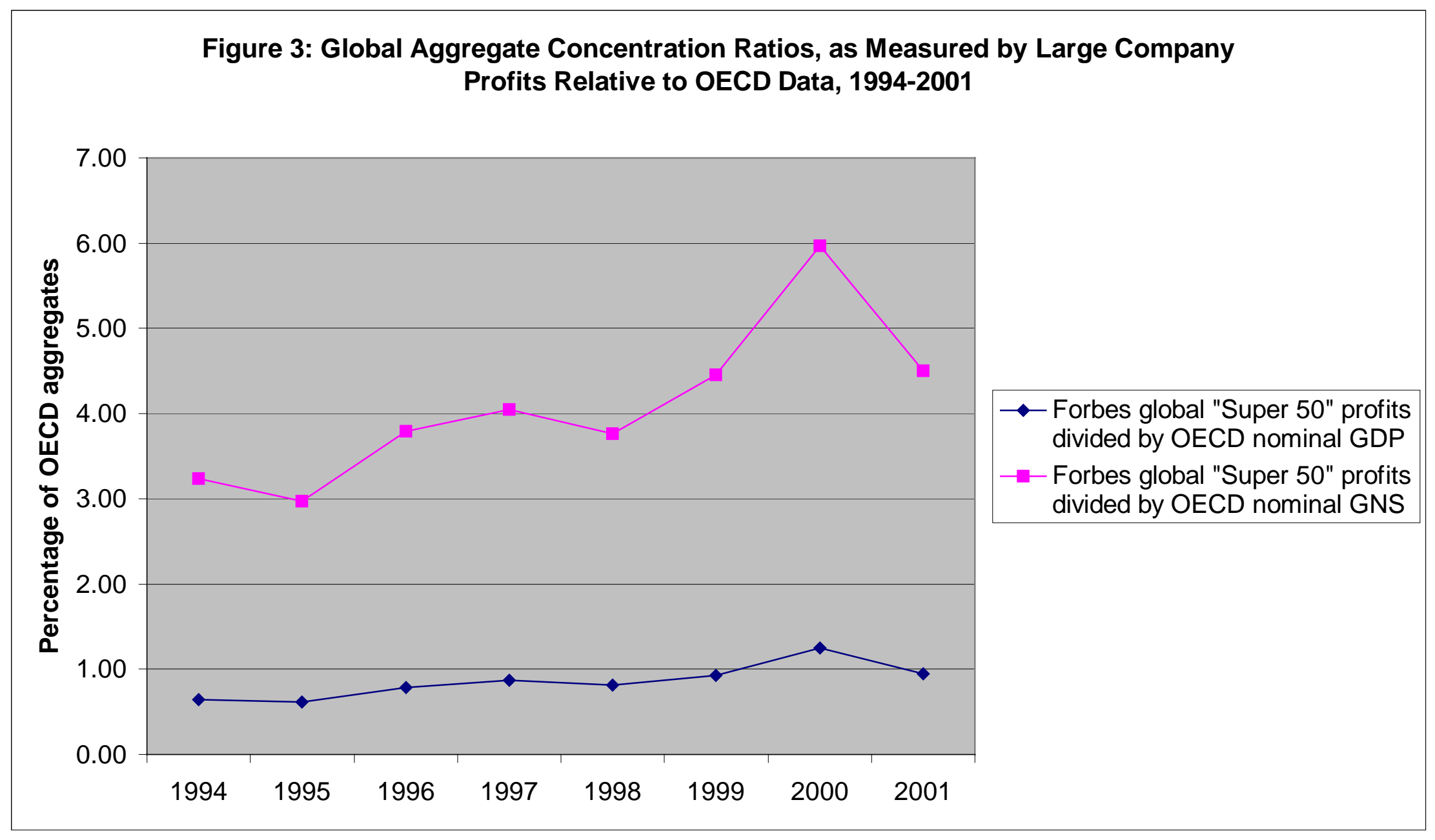

